\title{
ESTIMATION OF POISSON'S RATIO OF SOIL USING STIFFNESS OF LOOSE SOILS
}

Professional paper / Stručni rad

\section{Mikhailo Marchenko}

(Received: 5 May 2018; accepted: 21 June 2018)

Odessa State Academy of Civil Engineering and Architecture, Assist. Prof., PhD

Iryna Mosicheva

Odessa State Academy of Civil Engineering and Architecture, Lecturer, PhD.

\section{Aleksej Aniskin}

University North, Senior lecturer, $P h D$

Corresponding author: aaniskin@unin.hr

\begin{abstract}
A method for estimating the Poisson's ratio of soil from the in situ results of soil stiffness measurement is presented in detail. The results of measuring the settling of soil layers beneath a bearing plate via settlement gauges and that of measuring the dry density of soil before and after the loading are analyzed. A clear correlation between the soil stiffness and the Poisson's ratio is observed. Three similar magnitudes of the Poisson's ratio are calculated by three independent algorithms.
\end{abstract}

Keywords: bearing plate; settling; stiffness; bulk soil density; Poisson's ratio; coefficient of lateral expansion.

\section{KVANTITATIVNA OCJENA POISSONOVOG KOEFICIJENTA TLA PREMA PARAMETRIMA STIŠLJIVOSTI SLABIH TLA}

Sažetak: U radu je razrađena i prikazana metoda kvantitativne procjene vrijednosti koeficijenta bočnog širenja prema rezultatima ispitivanja stišljivosti tla u terenskim uvjetima. Analizirani su rezultati ispitivanja provedenih mjerenjem slijeganja slojeva u tlu ispod kružne ploče uz pomoć senzora slijeganja i određivanja gustoće suhog tla prije i nakon primjene opterećenja. Uspostavljena je jasna korelacija između veličine stišljivosti tla i koeficijenta bočnog širenja. Dobivene su bliske vrijednosti koeficijenta bočnog širenja uz pomoć tri nezavisna algoritma.

Ključne riječi: nosiva ploča; slijeganje; indeksi stišljivosti; gustoća suhog tla; Poissonov koeficijent; koeficijent bočnog širenja. 


\section{INTRODUCTION}

A geotechnical analysis of current construction practices shows that most collapses and damage involving buildings and structures are caused by soil collapse [1]. This is due to many factors. The most prominent factors are the various accepted calculation schemes and its basic assumptions, the assumptions in soil modeling, the natural variability in the deformative parameters of soils, and the drawbacks of conventional methods used in their determination.

Numerous experimental studies have shown that the standard calculation of settlements in water-saturated loess-like soils does not fully correspond to the parameters of their compressibility (Modulus of compression, Young modulus and etc.) and does not consider regional peculiarities. The calculated parameters in the settlement formula according to the linearly deformed half-space scheme $\left(\sigma_{z p}, H_{c}\right.$, and $\left.E\right)$ differ significantly from the real values [2-7].

One of the reasons for this discrepancy is the Poisson's ratio-in other words, the coefficient of lateral expansion $v$. Thus, in settlement calculations, the value of the dimensionless coefficient $\beta$ for all types and states of soils is taken to be 0.8 [8], although, in essence, it directly depends on the Poisson's ratio and it must be variable, i.e., it should take into account the ground conditions, area of the foundation, pressure transferred from foundation to soil, etc.

When elastic materials deform, the Poisson's ratio characterizes the relationship between transversal lengthening and longitudinal shortening and is one of the mechanical constants of materials. Its magnitude is not affected by the experimental conditions nor by how the deformation occurs. The Poisson's ratio represents a change in shape of a material while the volume is maintained constant.

In soil mechanics, Poisson's ratio, also known as the coefficient of lateral expansion, is affected by the following factors:

a) The soil is a discrete and stratified medium, mostly not elastic and anisotropic.

b) The soil is not deformed linearly.

c) Generally, local stress on the soil causes deformation only locally, compressing the soil longitudinally and expanding it transversally, with the surrounding soil resisting the deformation. Hence, the Poisson's ratio in soil mechanics is a rather conditional parameter.

The Poisson's ratio in work [9] represented as a function of the strength and physical parameters of the soil. The expression is obtained from the N. P. Puzyrevsky solution [10] for the end of the consolidation phase and the beginning of the shear phase, where the limiting equilibrium state is realized in the following form:

$$
v=\frac{0,5 \cdot \sigma_{1} \cdot\left(1-\sin \varphi_{I I}\right)-c_{I I} \cdot \cos \varphi_{I I}}{\sigma_{1}-c_{I I} \cdot \cos \varphi_{I I}}
$$

Where is $\sigma_{1}$ the first critical or "safe" pressure, $c_{\|}$is the specific cohesion, and $\varphi_{\|}$is the angle of internal friction.

The numerical values of the standard values of the Poisson's ratio obtained in this manner are listed in Table 1.

Table 1 Standard values of Poisson's ratio by values $c$ and $\varphi$

\begin{tabular}{cccccc}
\hline \multirow{2}{*}{ Type of Soil } & \multirow{2}{*}{ Liquid limit $\boldsymbol{L}$} & \multicolumn{4}{c}{ The Poisson's ratio $\boldsymbol{v}$ at a void ratio e equal to } \\
\cline { 2 - 5 } Sandy loam & $0 \leq \mathrm{IL} \leq 0.25$ & 0.55 & $\mathbf{0 . 6 5}$ & $\mathbf{0 . 7 5}$ & $\mathbf{0 . 8 5}$ \\
& $0.25 \leq \mathrm{L} \leq 0.75$ & 0.2402 & 0.2344 & 0.2556 & - \\
Loam & $0 \leq \mathrm{L} \leq 0.25$ & 0.2211 & 0.2556 & 0.2784 & 0.3030 \\
& $0.25 \leq \mathrm{L} \leq 0.50$ & 0.2332 & 0.2441 & 0.2424 & 0.2516 \\
& $0.50 \leq \mathrm{L} \leq 0.75$ & - & 0.2631 & 0.2555 & 0.2745 \\
Clay & $0 \leq \mathrm{L} \leq 0.25$ & - & 0.2281 & 0.2383 & 0.2955 \\
& $0.25 \leq \mathrm{L} \leq 0.50$ & - & 0.2415 & 0.2498 & 0.2472 \\
& $0.50 \leq \mathrm{L} \leq 0.75$ & - & 0.2622 & 0.2700 & 0.2840 \\
\hline
\end{tabular}

In compression-confined tests, with lateral deformations equal to zero, the value of the Poisson's ratio is determined by the following expression: 


$$
p_{x}=p_{y}=\frac{v_{0}}{1+v_{0}} p_{z}=\xi_{0} p_{z}
$$

Where $p_{x}$ and $p_{y}$ are the horizontal components and $p_{z}$ is the vertical component of the all-round pressure, $\xi_{0}$ is the coefficient of lateral pressure, and $v_{0}$ is Poisson's coefficient in the absence of lateral expansion.

The value of the lateral pressure $p_{x}$ at the corresponding vertical pressure $p_{z}$ can be measured [11]. However, lateral movement or lateral expansion, which occurs when real earth subgrades are being loaded (but not possible in compression tests), leads to a change in both $\xi_{0}$ and $v_{0}$. Therefore, the values of $\xi_{0}$ and $v_{0}$ are obtained by taking into account the dependence between the coefficient lateral pressure and the internal friction angle proposed by M. Jacy, $\xi_{0}=1-\sin \varphi$. These values are also used in calculations based on soil models with the possibility of a slight lateral expansion [12].

Bugaev et al. [13] proposed determining the Poisson's ratio through parallel testing of soil samples under special conditions in modernized compression instruments (glasses). One sample (standard) is tested via compression without the possibility of lateral expansion, and the second (made in the form of a thick-walled cylinder) is tested via internal radial loading. To eliminate the distorting effect of friction along the lateral surfaces of the glass, its walls are compressed in the axial direction [14]. The joint processing of the tests results uniquely determines the Poisson's ratio.

In soil mechanics, for a homogeneous and isotropic soil, the Poisson's ratio varies in the range $0 \leq v \leq 0.5$. If $v=0$, then the sample is compressed, without lateral expansion. If $v=0.5$, the soil goes into a plastic state and deforms without changing volume; only its shape is changed.

At low pressures, the Poisson's ratio for a given type of soil is considered to be constant [15]; the values are listed in Table 2.

Table 2 Poisson's ratio

\begin{tabular}{|c|c|c|}
\hline \multicolumn{2}{|c|}{ Type of Soil } & Коэффициент поперечной деформации v \\
\hline \multicolumn{2}{|c|}{ Sand and Sandy loam } & $0.30-0.35$ \\
\hline \multicolumn{2}{|c|}{ Loam } & $0.35-0.37$ \\
\hline Clay & $\begin{aligned} & L \leq 0 \\
0< & <\leq 0,25\end{aligned}$ & $\begin{array}{l}0.20-0.30 \\
0.30-0.38\end{array}$ \\
\hline & $0,25<\iota_{L} \leq 1,0$ & $0.38-0.45$ \\
\hline
\end{tabular}

Note: Lower values $v$ used for soil with higher density. [16]:

The most reliable values of $v$ are those obtained in the results of the triaxial tests using the following formula

$$
v=\frac{\sigma_{h} \cdot \varepsilon_{v}-\sigma_{v} \cdot \varepsilon_{h}}{\sigma_{h}\left(\varepsilon_{v}-2 \cdot \varepsilon_{h}\right)+\sigma_{v} \cdot \varepsilon_{v}}
$$

Here, $\sigma_{v}$ and $\sigma_{h}$ are the calculated vertical and horizontal stresses on the sample, respectively, and $\varepsilon_{v}$ and $\varepsilon_{h}$ are the measured vertical and horizontal deformations of the sample, respectively.

An analysis of the relevant literature [17-22] shows that the values of the Poisson's ratio, given by the authors, vary over a rather wide range and often differ from those recommended by normative documents [8]. Common disadvantages of such tests are

- Contact errors

- Friction between the specimen and plate

- Nonuniform distribution of horizontal deformations along the height of the sample

- Structure of the medium transmitting lateral pressure (water, gas) onto the sample

- Rigid support of the sample on the bottom plate, which in the case of real transfer of load to the foundation, is practically never realized.

Thus, one specific problem in nonlinear soil mechanics is the uncertainty when estimating the magnitude of the Poisson's ratio experimentally due to its dependence on many factors. Here, it is suggested that the Poisson's ratio be calculated using the fact that the Poisson's ratio is correlated to compressibility indices determined experimentally in situ. The Poisson's ratio should be found on the basis of the results of bearing plate tests by determining.

Marchenko, M, Mosicheva I, Aniskin, A 
- the general deformation of the supporting column according to the values of the difference between the bearing plate settlement and the settlement gauge

- the bulk deformation (compaction in the vertical direction) of the supporting column caused by the establishment of changes in the density of dry soil

- the lateral deformation of the supporting column (additional settlement) due to a change in its shape, as the difference between the total and bulk deformation;

- the ratio of the relative lateral strain to the relative longitudinal strain

\section{MATERIAL AND METHODS}

\subsection{In situ materials and measuring method}

Two case studies of in situ soil testing [23, 24] were considered. Based on them, an analytical study of the Poisson coefficient was made.

The soil geological profile on the site of the first case study [23] included three soil layers with thicknesses as follows: humus of $1.1 \mathrm{~m}$, a light yellow loess of 4-6 m, and a layer of yellow loess 6.3 to $9.0 \mathrm{~m}$ thick. The plate bearing tests were conducted in the second layer at a depth of $2 \mathrm{~m}$, using square plate dimensions of $0.707 \times 0.707$ $\mathrm{m}$. The final contact stress beneath the plate base was $0.3 \mathrm{MPa}$, and the settlement was $0.19 \mathrm{~m}$. The soil characteristics of the tested soil layer are listed in Table 3. In the second work [24], the geological profile of the soil was as follows: humus of $0.6 \mathrm{~m}$, light-brown loess-like loam with a thickness of $2.1 \mathrm{~m}$, and light-yellow loess-like loam with a thickness of $3.1 \mathrm{~m}$. The tests were carried out in a second layer at a depth of $2.2 \mathrm{~m}$ using a square bearing plate of $1.41 \times 1.41 \mathrm{~m}$. The final contact stress beneath the plate base was $0.35 \mathrm{MPa}$, and the settlement was $0.38 \mathrm{~m}$. The soil characteristics of the tested soil layer are listed in Table 3.

Table 3. Soil characteristics in situ [23,24]

\begin{tabular}{ccc}
\hline Soil characteristic & Raevski I.E. experiment [23] & Tugaenko Yu.F. experiment [24] \\
\hline$\rho_{s}$, particle density & $2,68 \mathrm{~g} / \mathrm{cm}^{3}$ & $2,66-2,68 \mathrm{~g} / \mathrm{cm}^{3}$ \\
$\rho$, bulk density & $1,55 \mathrm{~g} / \mathrm{cm}^{3}$ & $1,70-1,71 \mathrm{~g} / \mathrm{cm}^{3}$ \\
$\rho_{d}$, dry density & $1,47 \mathrm{~g} / \mathrm{cm}^{3}$ & $1,35-1,45 \mathrm{~g} / \mathrm{cm}^{3}$ \\
$e$, void ratio & 0,82 & $0.83-0,96$ \\
$S_{r}$, degree of saturation & 0,154 & $0,68-0,79$ \\
$W$, moisture content & 0,122 & $0,11-0,14$ \\
$W_{L}$, liquid limit & 0,224 & $0,29-0,32$ \\
$W_{P}$, plastic limit & 0,183 & $0,18-0,19$ \\
$I_{P}$, plasticity index & 0,041 & $0,11-0,13$ \\
$I_{L}$ liquidity index & $<0$ & $0,213-0,25$ \\
\hline
\end{tabular}

The tests were carried using bearing plates loaded gradually in several phases. During the loading phase, the settlement was measured by the settlement gauge (Fig. 1a).

The settlement gauge (Fig. 1a) consisted of a circular body with two lateral antirotation knife stabilizers. Measurements of the altitude position of the magnet rings (Fig. 1b) were conducted by a sensor (capsule with reed switch) hung on the steel measuring tape.

The load on the bearing plate was applied stepwise using standard metal loads, with the criterion of stabilization of each stage equal to $0.1 \mathrm{~mm} / \mathrm{day}$. At the initial stage of the tests, the steps were 1 metric ton and then increased to $5 \mathrm{t}$. Measurements of the settlement gauge displacement were carried out from the reference system, with an accuracy of $0.1 \mathrm{~mm}$.

The Poisson's ratio of soil $v$, implicitly, as the coefficient $\beta=0.8$, was used in the settlement in different design schemes and ground base models [8]. It plays a special role in calculating the average settlement of water-saturated bases over time, considering the filtration consolidation and creep of the soil skeleton. 


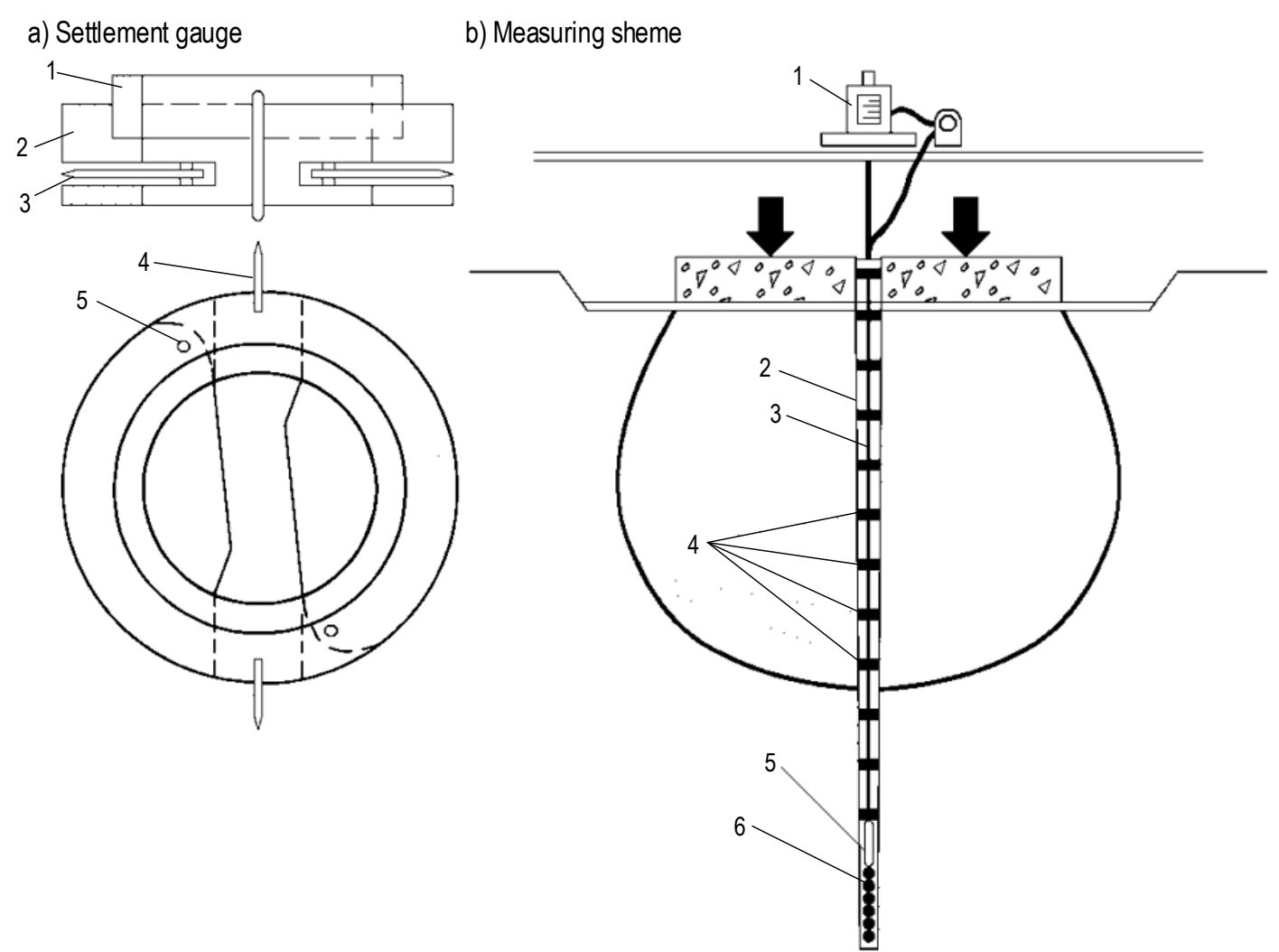

Figure 1 a) Construction of the settlement gauge: 1 - magnetic ring, 2 - circular body of gauge; 3 - anchor blades; 4 - antirotation knife stabilizers; 5 - axis of rotation of the anchor segment cover. b) Settlement measurement procedure: 1 - measuring instrument; 2 - protective bore tube; 3 - electrical conductor with a measuring tape; 4 - settlement gauges; 5 - reed switch; 6 - weights.

\subsection{Analytical solution for Poisson's ratio}

The basic premise of the method used is the assumption that only the soil column directly underneath the bearing plate carries the entire load, as depicted in Fig. 2a [25] (in which we already accepted Winkler's model of soil). The assumption is that the vertical settling of horizontal layers of the soil column is uniform at every depth and determined by the difference of the displacements measured by the settlement gauge beneath the bearing plate. Another assumption is that stresses only act under the bearing plate (inside the supporting column) causing soil compaction (densification), which in turn causes horizontal expansion.

Foundation settling is a consequence of stresses acting on the foundation and is a result of two mutually dependent and mutually conditioned processes. First, soil deformation is usually accompanied by a change in the soil volume caused by the change in the pore volumes (compression). After reaching a certain limiting point, the supporting column of soil starts to expand transversally with the shape of the column of the compacted soil changing, as depicted in Fig. 2a.

Thus, the total vertical deformation of the horizontal layer of soil, measured between the installed settlement gauges, is the sum of the deformation caused by compression and the deformation caused by the change in shape:

$$
S=S_{n}+S_{V}
$$

where $S_{n}$ is the compression deformation of a horizontal layer of soil due to the shrinking of pores in the soil, and $S_{v}$ is the compression deformation caused by horizontal broadening or simply by the change in shape. 


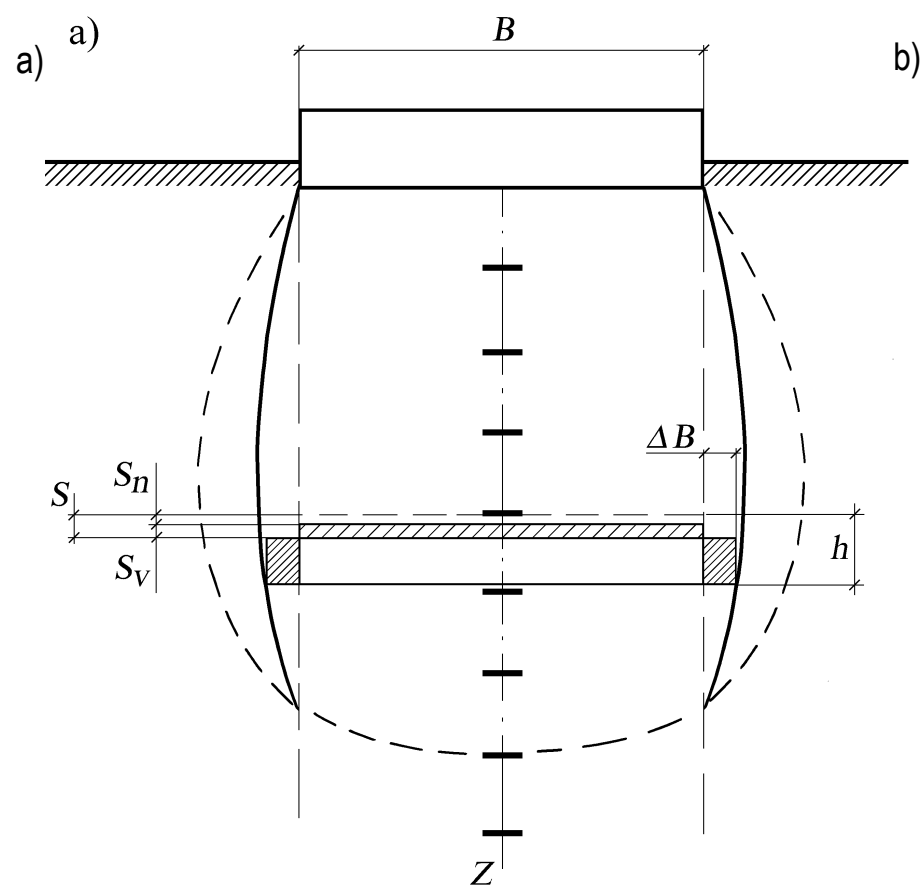

b) б)

c)

Change in lateral expansion
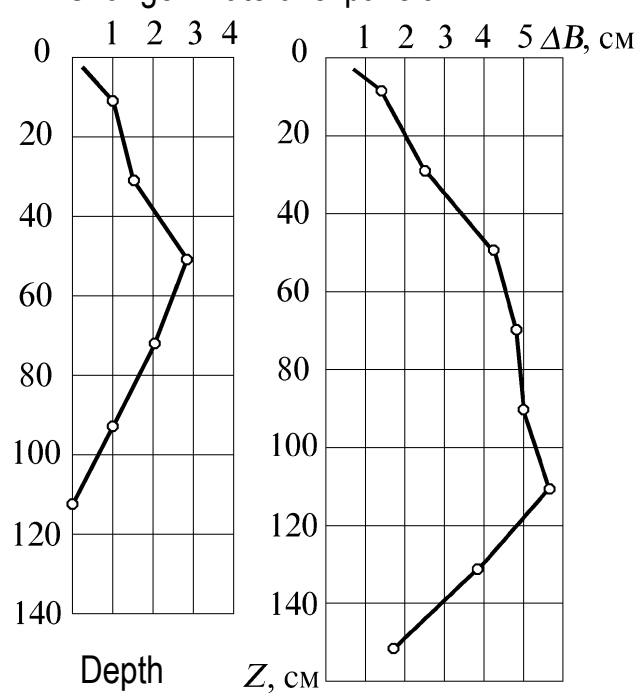

Figure 2 (a) Depiction of the manner in which a supporting soil column deforms; (b) transversal displacement calculated according to the experimental results of Raevsky, I.E. [24] and (c) Tugayenko, Yu. F. [25]

Methodically, the algorithm calculating the Poisson's ratio consists of the following steps.

1) The compression deformation of a horizontal layer of soil caused by compaction is determined from the change in the bulk density of a dry soil is given by

$$
S_{n}=h\left(1-\rho_{d} / \rho_{d}^{y}\right)
$$

with $\rho_{d}$ and $\rho_{d}^{y}$ being the bulk densities of the dry soil, as measured in its natural state and after being compressed because of the foundation load.

2) The part of the deformation that stems from lateral expansion, i.e., only from the change in the shape of the supporting soil column, is determined from the difference in the settlements measured by the settlement gauge by Equation (4) using the data from Equation (5):

$$
S_{V}=S-S_{n}
$$

3) The lateral expansion of the supporting soil column, $\Delta B$, is estimated by assuming that the volume of the vertically compressed soil and the volume of the horizontally displaced soil are equal:

$$
S_{V} A=\Delta B(h-S) u
$$

$A=B^{2}$ is the supporting soil column cross-sectional area; $h$ and $S$ are the height and the total compression deformation of the horizontal layer of the soil, respectively, as measured between the settlement gauge marks at a certain depth; and $u$ is the average circumference (length) of the supporting column, forming the volume of lateral expansion. In the first approximation and for a square footing, one can use $u=4 B$ in Equation (7) and find:

$$
\Delta B=0,25 B S_{v} /(h-S)
$$

Fig. 2 shows the change in the calculated linear values of lateral expansion of the supporting column with respect to the depth for bearing plate with an area of $0.5 \mathrm{~m}^{2}(\mathrm{~b})$ and $1.0 \mathrm{~m}^{2}$ (c) at a contact stress of $0.3 \mathrm{MPa}$ and $0.35 \mathrm{MPa}$, respectively, on water-saturated loess soils $[24,25]$.

Marchenko, M, Mosicheva I, Aniskin, A 
Based on the experimental data, an estimate of the values of the lateral expansion coefficient was carried out by three independent methods, algorithmically based on the following assumptions.

First, it is assumed that the ground resists the external load according to the uniaxial compression scheme of the supporting column with the possibility of its limited barrel-like lateral expansion, which is constrained by the surrounding soil continuum. On this basis, the Poisson's ratio can be determined from the ratio of the maximum value of the relative lateral expansion found from the following expression

$$
\varepsilon_{x}=\frac{2 \Delta B_{\max }}{B}
$$

and relative longitudinal compression averaged by the height of the supporting column, which defined by the following expression:

$$
\varepsilon_{z}=\frac{S}{H_{a}}
$$

Thus, we obtain

$$
v=\frac{\varepsilon_{x}}{\varepsilon_{z}}=\frac{\varepsilon_{y}}{\varepsilon_{z}}=\frac{2 \Delta B_{\max } H_{a}}{B \cdot S_{u}}
$$

Where $2 \Delta B_{\max }$ is the maximum value of the lateral expansion of the supporting column, $S_{u}$ is the settlement of a bearing plate, and $H_{a}$ is the measured depth of the compressed supporting column.

As a result, the value of the Poisson's ratio, obtained taking into account the accepted assumption, is close to $\mathrm{v} \cong 0.40[26]$.

The second assumption is similar to the first assumption, with the only difference being that the supporting column has the possibility of being bounded, but uniform along the height expansion [27], which ultimately leads to Equation (11) becoming

$$
v=\frac{2 \Delta B_{c p} H_{a}}{B \cdot S_{u}}
$$

Where $\Delta B_{c p}=\frac{\Sigma \Delta B_{i}}{n}$ is the averaged uniform lateral expansion of the supporting column by depth.

As a result of the processing of the initial data by this criterion, the value of Poisson's ratio can be estimated as $\mathrm{V} \cong 0.30$ [28].

The third assumption can be called piecewise discrete, because it realizes layer-wise determination of the Poisson's ratio by the depth of the support column. The relative lateral expansion values in this case are layer-wise, calculated by the expression that, taking into account (8), becomes

$$
\varepsilon x=\varepsilon y=\frac{2 \Delta B}{B}=\frac{0,5 S_{v}}{h-S}
$$

Fig. 3a shows the changes in the values of the relative lateral deformations along the depth of a bearing plate.

The values of the relative longitudinal deformations along the depth of the supporting column were calculated layer-wise using the displacement data of the settlement gauges:

$$
\varepsilon_{z}=\frac{S}{h}
$$

The change in depth of the supporting column is depicted in Fig. 3b. From the ratio of the corresponding values of $\varepsilon_{x}$ and $\varepsilon_{z}$ (Figs. 3a and $b$ ), the values of the Poisson's ratio are determined layer by layer by the following expression:

$$
v=\frac{\varepsilon_{x}}{\varepsilon_{z}}=\frac{\varepsilon_{y}}{\varepsilon_{z}}=\frac{0,5 \cdot S_{v} \cdot h}{(h-S) \cdot S}
$$


The diagrams showing the Poisson's ratio as a function of the depth of the supporting column are depicted in Fig. 3c.
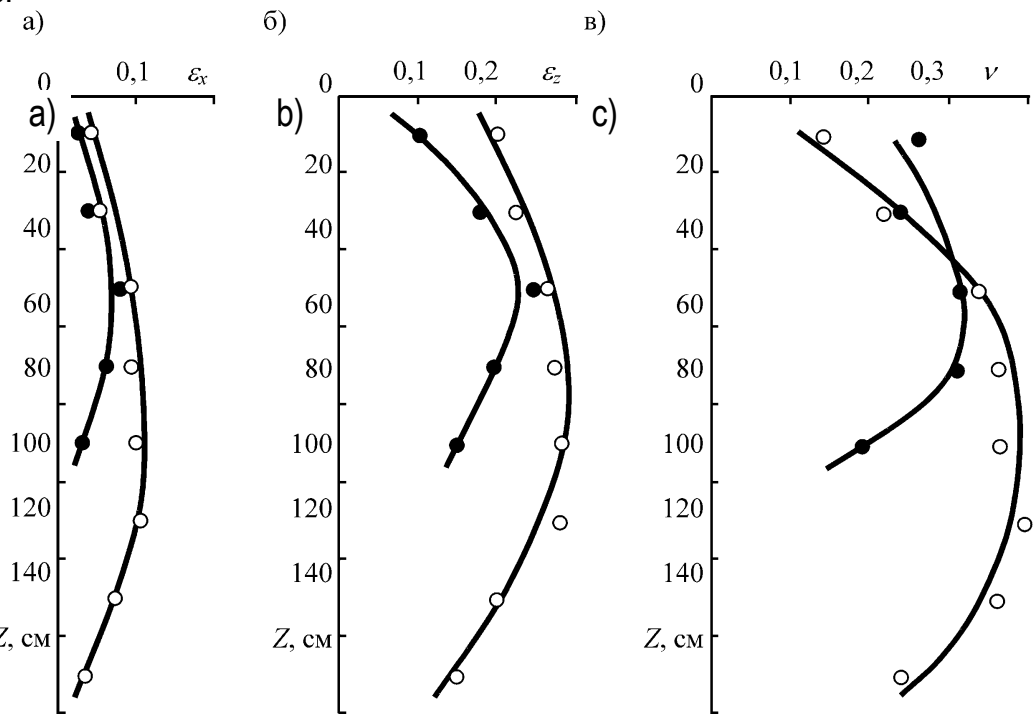

- a plate with an area of $0.5 \mathrm{~m}^{2}$, pressure on contact plate-soil $0.3 \mathrm{MPa}$.

- hollow dots represent a plate with an area of $1.0 \mathrm{~m}^{2}$, pressure on contact plate-soil $0.35 \mathrm{MPa}$.

Figure 3 (a) Depiction of the relative transverse $\varepsilon_{x}$ and (b) relative longitudinal $\varepsilon_{z}$ deformations and (c) Poisson's ratio $v$ value changes according to depth under a bearing plate loaded on water-saturated loess soils based on the experiments of I. E. Rayevsky [23] and Yu. F. Tugaenko [24]

Relying on the existing base of experimental studies on soil compressibility, it can be stated that the value of the Poisson's ratio of soil depends on the type, physical characteristics, and stress-strain state of the soil. In addition, the Poisson's ratio varies along the height of the support column. Its value is influenced by the dimensions, area, pressure on contact with soil, depth of the foundation, and other parameters of the foundation. The definition of its magnitude also depends on the accepted initial methodological position and the algorithm for its calculation.

\section{CONCLUSIONS}

Based on the results of the presented analytic solution for Poisson's ratio based on stiffness of loose soils it is concluded that:

1. The physical meaning of the Poisson's ratio interpretation for soil grounds is rather ambiguous, and its magnitude depends on multiple factors, including the consequence of the accepted initial assumptions and the method of determination. Thus, its value, taking into account the first assumption (11), is close to the value $v \cong 0.4$. The second assumption (12) is estimated by the value $v \cong 0.3$, which is a $25 \%$ lower value. In the method with the third assumption (15), the value of $v$ is not constant by depth. It increases up to the depth of ca $1 \mathrm{~m}$; then, with further increases in depth, it returns approximately to the initial value on the surface (Fig. 3c).

2. The magnitude of the Poisson's ratio is multifactorial and depends on the following:

a) Plan area of the foundation - the larger the area, the smaller is the coefficient of transverse expansion.

b) Contact pressure along the foundation base - at higher pressures values, the Poisson's ratio increases.

c) Density of soil subgrade - with increasing soil density, the Poisson's ratio decreases.

d) Moisture index - with an increase in moisture index, the value of the Poisson's ratio increases.

3. The proposed method and algorithms for estimating the value of the Poisson's ratio (coefficient of lateral expansion) under in situ conditions require further improvement and refinement to increase amount of initial data for analysis and to reveal the main regularities.

\section{References}

[1] Terzaghi K.; Peck R.B.; Mesri Gh. 1996: Soil Mechanics in Engineering Practice, 3rd Edition, John Wiley \& Sons, USA, $592 p$

Marchenko, M, Mosicheva I, Aniskin, A 
[2] Dolmatov B. I.; Sotnikov S.N.; Doroshkevich N.M. et.al. 1973: Issledovaniye deformatsiy gruntov v osnovanii sooruzheniy, Trudy k VIII-mu Mezhdunarodnomu kongressu po mekhanike gruntov i fundamentostroyeniyu, M: Stroyizdat, S.64-72 (In Russian)

[3] Yegorov K.Ye; Nichiporovich A.A. 1961: Issledovaniye deformatsiy osnovaniy, Doklady k V Mezhdunarodnomu kongressu po mekhanike gruntov i fundamentostroyeniyu., M: Gosstroyizdat, S. 95-105 (In Russian)

[4] Konovalov P.A.; Usmanov R.A. 1983: Issledovaniye deformatsiy sil'no szhimayemykh osnovaniy gibkikh shtampov i rezervuarov, General'nyye doklady i spetsial'nyye lektsii k VII Dunaysko-Yevropeyskoy konferentsii po mekhanike gruntov i fundamentostroyeniyu. T. 3, Kishinev, S. 107-112 (In Russian)

[5] Malikova T.A. 1972: Analiz natural'nykh osadok plitnykh i korobchatykh fundamentov mnogoetazhnykh zdaniy, Osnovaniya, fundamenty i mekhanika gruntov, №2, S. 17-21 (In Russian)

[6] Roshchin V.V. 1965: Priblizhennaya formula raspredeleniya napryazheniy pod fundamentami $v$ grunte /I Materialy Vsesoyuznogo soveshchaniya po stroitel'stvu na slabykh vodonasyshchennykh glinistykh gruntakh, Tallin, S. 187-191 (In Russian)

[7] Tugayenko YU.F.; Matus YU.V.; Marchenko M.V. 1988: Deformatsii osnovaniy zdaniy na plitnykh fundamentakh $\vee \mathrm{g}$. Odesse, Stroitel'nyye konstruktsii, stroitel'nyye materialy, inzhenernyye sistemy, ekologicheskiye problemy, sb. nauchn. trudov OGASA, Odessa: IMK «Gorod masterov», S. 45-46 (In Russian)

[8] DBN V.2.1-10-2009. Osnovaniya i fundamenty sooruzheniy, Osnovnyye polozheniya proyektirovaniya, Kiyev, Minregionstroy Ukrainy,104 s (In Ukrainian)

[9] Vinnikov Yu.L.; Mukha V.A.; Yakovlêv A.V. et.al. 2002: Fundamenti budível' í sporud. Dovídkoviy posíbnik, K.: Urozhay, 423 s. (In Ukrainian)

[10] Tsytovich N.A. 1987: Soil Mechanics, Mir Publishers; English Translation edition, 288 p

[11] Lazebnik G.Ye.; Smirnov A.A.; Simakov V.I. 1967: Eksperimental'noye opredeleniye koeffitsiyenta $\square$ bokovogo davleniya i koeffitsiyenta Puassona nesvyaznykh gruntov, Osnovaniya, fundamenty i mekhanika gruntov., № 4., S. 17-20. (In Russian)

[12] Kleyn G.K. 1977: Stroitel'naya mekhanika sypuchikh tel, M.: Stroyizdat, 256 s. (In Russian)

[13] Bugaêv V. T.; Kovtun V.V.; Kolesnikova Ye.V. 2003: Eksperimental'noye obespecheniye avtomatizirovannogo proyektirovaniya portovykh gidrotekhnicheskikh sooruzheniy, Vísnik Odes'kogo natsíonal'nogo mors'kogo universitetu, Odesa: ONMU, Vip.10, S. 186-191 (In Russian)

[14] Kovtun V.V.; Bugaêv V. T. 1972: Pribor dlya opredeleniya modulya deformatsii gruntov, Seysmostoykost' gidrotekhnicheskikh i portovykh sooruzheniy, Vladivostok, S. 78-80 (In Russian)

[15] Proyektirovaniye i ustroystvo osnovaniy i fundamentov zdaniy i sooruzheniy. 2005, SP 50-101, M., 129 s. (In Russian)

[16] Kushner S.G. 2008: Raschot deformatsiy osnovaniy zdaniy i sooruzheniy. Zaporozh'ye, OOO «Zaporozh'ye», 496 s (In Russian)

[17] Semashko S.V. 2010: Koeffitsiyent Puassona, poristost' i raskrytiye mikrotreshchin v glubinnykh chastyakh zemnoy kory, Izvestiya Tul'skogo gosudarstvennogo universiteta. Nauki o zemle, № 2, S. $35-37$ (In Russian)

[18] Doroshenko S.P.; Saenko Y.V.; Nevzorov A.L. 2016: Determination of soil Poisson's ratio based on numerical simulation of laboratory test, PNRPU Bulletin Construction and architecture, Vol. 7, No. 2. pp. 60-68, DOI: 10.15593/2224-9826/2016.2.06

[19] Suwal L.P.; Kuwano R. 2012: Poisson's ratio evaluation on silty and clayey sands on laboratory speicmens by flat disk shaped piezo-ceramic transducer, Bulletin of ERS, № 45, C. 141-158

[20] Putri E.E.; Rao N.S.V.K.; Mannan M.A. 2012: Evaluation of modulus of elasticity and modulus of subgrade reaction of soils using CBR test, Journal of Civil Engineering Research, Vol. 2, No. 1, pp. 34-40, DOI: 10.5923/j.jce.20120201.05

[21] Zhang J.J.; Laurence R. 2005: Bentley Factors determining Poisson's ratio, CREWES Research Report., Vol. 17.

[22] Briaud J.L. 2001: Introduction to Soil Moduli, Geotechnical News, Richmond, B.C., Canada: BiTech Publishers Ltd.

[23] Rayevskiy I.Ye. 1962: Vliyaniye razmerov shtampov na kharakter prosadki lessovykh gruntov, Osnovaniya. fundamenty i mekhanika gruntov. № 5. - S. 14-18. (In Russian) 
[24] Tugayenko YU.F. 1966: Eksperimental'nyye issledovaniya sovmestnoy raboty osnovaniy i fundamentov v lessovykh gruntakh I tipa, Izvestiya vuzov. Stroitel'stvo i arkhitektura., № 2. - S. 22-31. (In Russian)

[25] Gol'dshteyn M.N.; Kushner S.G. 1970: Inzhenernyy metod rascheta osadok fundamentov pri davleniyakh. prevyshayushchikh normativnyye, Osnovaniya. fundamenty i mekhanika gruntov № 5. - S. 13-17. (In Russian)

[26] Marchenko M.V. 2003: Mnogofaktornost' kolichestvennoy otsenki koeffitsiyenta bokovogo rasshireniya vodonasyshchennykh lossovykh gruntov, Zb. nauk. prats'. "Galuzeve mashinobuduvannya. Budívnitstvo», Vip. 12, Poltava: PNTU ím.. YU. Kondratyuka. S. 130-135. (In Russian)

[27] Rekomendatsii po metodam opredeleniya koeffitsiyentov bokovogo davleniya i poperechnogo rasshireniya glinistykh gruntov. 1978.: NIIOSP im. N.M. Gersevanova., M.: TSINIS Gosstroya SSSR. 30 s. (In Russian)

[28] Marchenko M.V. 2003: Ímovírnísne traktuvannya koyefítsiênta Puassona po yeksperimental'nim doslídzhennyam pokaznikiv stislivostí, Vísnik Odes'kogo natsíonal'nogo mors'kogo uníversitetu, Zb. nauk. prats'., Vip. 10 - Odesa: ONMU. S. 232-237. (In Ukrainian)

Please cite this article as:

Marchenko, M, Mosicheva I, Aniskin, A: Estimation of Poisson's ratio of soil using stiffness of loose soils, Electronic Journal of the Faculty of Civil Engineering Osijek-e-GFOS, 16, pp. 85-94, https://doi.org/10.13167/2018.16.8 